\title{
Arah dan Orientasi Filsafat IImu di Indonesia
}

\author{
Hastangka ${ }^{1}$, Heri Santoso ${ }^{2}$ \\ ${ }^{1}$ Magister Psikologi, Universitas Mercu Buana Yogyakarta, Indonesia \\ 2 Fakultas Filsafat, Universitas Gadjah Mada Yogyakarta, Indonesia \\ E-mail: hastangka@mercubuana-yogya.ac.id ${ }^{1}$, herisantoso@ugm.ac.id²
}

\begin{abstract}
Abstrak
Filsafat IImu merupakan salah satu cabang khusus dari Filsafat yang memiliki kedudukan dan posisi yang strategis dalam membangun paradigma ilmu di Indonesia. Penelitian ini akan mengkaji dan mendeskripsikan tentang kedudukan dan posisi Filsafat dalam paradigma keilmuan yang berkembang. Beberapa hal yang dibahas dalam penelitian ini adalah berikut ini. Pertama, kedudukan dan posisi Filsafat IImu sebagai paradigma di Indonesia. Kedua, perkembangan dan pengajaran Filsafat IImu dalam perkuliahan mata kuliah Filsafat IImu di Indonesia, secara khusus perkembangan buku teks yang ada. Ketiga, orientasi Filsafat IImu sebagai disiplin ilmu dari Filsafat yang berkembang di Indonesia. Tujuan dari kajian ini adalah untuk mendeskripsikan dan menganalisis tentang orientasi dan perkembangan Filsafat IImu di Indonesia dari aspek paradigma ilmu dan sejarah pemikirannya melalui kajian teks dan buku yang diterbitkan di Indonesia. Metode penelitian yang digunakan adalah pendekatan kualitatif dengan menganalisis sumber atau data dari buku teks, jurnal ilmiah, dokumen, silabus, dan bahan ajar dalam perkuliahan Filsafat IImu. Analisis yang digunakan adalah interpretasi, heuristik, dan refleksi filosofis. Hasil dari penelitian ini menunjukkan bahwa Filsafat Ilmu dikembangkan dan diajarkan mengacu pada paradigma Filsafat Ilmu yang berkembang di barat. Struktur yang dibangun dalam mengembangkan Filsafat Ilmu muncul dari kajian Filsafat mulai dari pengetahuan dasar tentang Filsafat sampai pada hakikat ilmu. Orientasi Flsafat IImu sebagai disiplin ilmu dari Filsafat yang dikembangkan di Indonesia dari berbagai literatur yang berkembang masih didominasi pada orientasi Filsafat barat.
\end{abstract}

Kata Kunci: filsafat ilmu; orientasi; paradigma; pemikiran; Indonesia.

\begin{abstract}
Philosophy of Science as a branch of science of Philosophy has a position and strategic position in building the paradigm of science in Indonesia. This study will examine and describe the position of Philosophy of science in a developing scientific paradigm. In this study, will questioning about how the position of Philosophy of Science as a paradigm in Indonesia. Second, how Philosophy of Science is developed and taught in lectures on Philosophy of Science in Indonesia specifically the development of existing textbooks. Third, how is the orientation of Philosophy of Science as a scientific discipline of Philosophy that develops in Indonesia. The purpose of this study is to describe and analyze the orientation and development of the Philosophy of Science in Indonesia from the aspect of the paradigm of science and the history of thought through the study of texts and books published in Indonesia. This research method uses a qualitative method approach by analyzing sources or data from textbooks, scientific journals, documents, syllabus, and teaching materials in Philosophy of Sciences. The analysis used is interpretation, heuristics, and philosophical reflection. The results of this study indicate that the Philosophy of Science was developed and taught based on the paradigm of Western the Philosophy of Science paradigm. The structure built in developing the Philosophy of science arises from the study of Philosophy starting from the basic knowledge of Philosophy to the nature of science. The orientation of Philosophy of science as a scientific discipline of Philosophy which developed in Indonesia from a variety of literature that existed is still dominated by the orientation of western Philosophy.
\end{abstract}

Keywords: philosophy of science; orientation; paradigm; thought; Indonesia. 


\section{Pendahuluan}

Persoalan ilmiah selalu menjadi perhatian bagi kalangan ilmuwan. Cara pandang dan orientasi dalam menghadapi persoalan ilmiah berpengaruh pada metode dan hakikat kebenaran ilmiah dicapai atau ditemukan. Untuk itu, Filsafat IImu menjadi dasar berpijak penting bagi para ilmuwan dan akademisi untuk menjawab persoalan ilmiah yang muncul pada setiap bidang ilmu yang didalami. Kajian tentang orientasi Filsafat Ilmu di Indonesia menjadi penting untuk dilakukan karena setiap masyarakat ilmiah memiliki orientasi dan paradigma dalam memosisikan persoalan ilmiah dan hakikat ilmu dalam konteks sosial, sejarah, politik, ekonomi, budaya, dan geografi. Kritik yang selalu muncul dari kelompok kalangan pragmatis dalam melihat posisi Filsafat IImu ialah "apa gunanya Filsafat IImu?" "apa itu Filsafat IImu?" pertanyaan ini menjadi perdebatan sepanjang tahun dan abad, tidak ada suatu jawaban yang dapat memuaskan dalam menjawab pertanyaan mendasar tersebut. Tradisi berpikir ilmiah ini berkembang secara umum di negaranegara Eropa. Filsafat IImu menjadi bagian proses tradisi berpikir ilmiah dan merupakan salah satu cabang Filsafat khusus. Menurut Kirom (2011), Filsafat IImu berkembang sejak zaman Yunani kuno, Filsafat IImu merupakan produk pengetahuan dari barat yang berakar pada perkembangan ilmu pengetahuan pada abad ke-17, yang pada waktu itu ilmu dan Filsafat berdiri sendiri.

Whitrow (1956) memaparkan tentang beberapa persoalan tentang Filsafat IImu sebagai berikut. Pertama, kehadiran Filsafat IImu sebagai suatu sikap dan posisi dalam menentukan hakikat dan makna tentang ilmu, sehingga Filsafat IImu ilmu dapat menjadi klaim seorang ilmuwan untuk memosisikan dirinya dalam suatu kasus pengetahuan. Kedua, Kedudukan Filsafat ilmu masih dipahami sebagai bidang ilmu yang berdiri sendiri dan mandiri, sehingga secara umum masih menjadi subjek yang bertolak belakang. Asumsi yang berkembang ialah bahwa tidak ada Filsafat ilmu, yang ada ialah berfilsafat tentang ilmu. Ketiga, Filsafat Ilmu dipersepsikan sama dengan ilmu yang lain yang dipelajari untuk suatu pencarian ilmu yang ingin mendalami spesialisasinya. Keempat, orang yang belajar Filsafat IImu tidak hanya sekedar belajar tentang ilmu tetapi juga belajar tentang bagaimana proses ilmiah itu bekerja.

Perkembangan pemikiran dan Sejarah Filsafat IImu di Indonesia berdasarkan pelacakan studi literatur masih belum nampak mulai dari mana dan kapan Filsafat IImu di Indonesia mulai dikembangkan dan dipelajari. Temuan awal yang muncul secara institusi bahwa Filsafat IImu mulai dipelajari dan dikembangkan bersamaan dengan terbentuk Fakultas Filsafat di Indonesia yang dirintis di Universitas Gadjah Mada. Fakultas Filsafat untuk pertama kalinya mengembangkan berbagai mata kuliah terkait dengan Filsafat, secara khusus Filsafat IImu, pada tahun 1960an. Hal tersebut terjadi sejak Fakultas Filsafat terpisah sebagai Fakultas yang berdiri sendiri dari Fakultas Filsafat, Sastra dan Pedagogik. Sedangkan secara pemikiran, jejak Filsafat IImu mulai nampak pada periode tahun 1970-an. Pada saat itu, berbagai hasil karya tentang Filsafat IImu mulai berkembang sampai sekarang meskipun dalam jumlah terbatas.

Kajian ini akan memfokuskan tentang orientasi Filsafat IImu di Indonesia dengan mengajukan beberapa pertanyaan penuntun yaitu: (1) Bagaimana orientasi Filsafat IImu di Indonesia dikembangkan? (2) Paradigma apa yang menjadi acuan dari pengembangan Filsafat IImu di Indonesia? dan (3) Bagaimana konteks penemuan (context of discovery) dan justifikasi (context of Justfication) atas kedudukan dan posisi Filsafat llmu di Indonesia? Nantinya, sumber data yang digunakan dalam penelitian ini berupa jurnal ilmiah, buku, berita cetak maupun elektronik, dan publikasi yang relevan terkait dengan topik ini. Analisis yang digunakan adalah analisis koherensi, interpretasi, dan induktif. Kerangka teoritis dalam penelitian ini menggunakan kerangka hakikat ilmu sebagai proses dan produk untuk mendapatkan pengetahuan. Menurut Akromullah (2018), ilmu yang pada hakikatnya mempelajari alam sebagaimana adanya mulai mempertanyakan hal-hal yang bersifat seharusnya: untuk apa sebenarnya ilmu itu harus dipergunakan? Di mana batas wewenang penjelajahan keilmuan? Ke arah mana perkembangan keilmuan harus diarahkan? Secara sistematis, ilmu (science) memiliki dua makna, yaitu sebagai produk dan sebagai proses. Sebagai produk, ilmu adalah pengetahuan yang sudah dikaji kebenarannya dalam bidang tertentu dan tersusun dalam suatu sistem. Sebagai proses, ilmu menunjuk pada kegiatan akal budi manusia untuk memperoleh pengetahuan dalam bidang tertentu secara bertatanan (stelselmatig) atau sistematis dengan menggunakan seperangkat pengertian yang secara khusus diciptakan untuk itu, untuk mengamati gejala-gejala (gegevens) yang relevan pada bidang tersebut, yang hasilnya berupa putusan-putusan yang keberlakuannya terbuka untuk dikaji oleh orang lain berdasarkan kriteria yang sama dan sudah disepakati atau yang dilazimkan dalam lingkungan komunitas keahlian dalam bidang yang bersangkutan (Tutik, 2014). 
Arah dan orientasi Filsafat IImu di Indonesia perlu mendapatkan perhatian, karena selama ini arah dan orientasi Filsafat IImu di Indonesia masih belum diuraikan dasar-dasar ontologis, epistemologis, dan aksiologis sebagai sistem pengetahuan yang berkembang di Indonesia menjadi ilmu. Studi yang dilakukan Achadah dan Fadil (2020) menjabarkan tentang Filsafat IImu dalam pertautan antara aktivitas ilmiah, metode ilmiah, dan pengetahuan sistematis, belum menunjukkan arah dan orientasi Filsafat IImu yang dikembangkan atau berkembang di Indonesia. Dalam tulisan tersebut, keduanya menjelaskan hakikat ilmu dan pengertian Filsafat IImu sebagai cara pandang untuk mendapatkan pengetahuan. Studi Butts (1974) yang menguraikan tentang Filsafat IImu di Canada (Philosophy of science in Canada), menunjukkan bahwa Filsafat IImu di Canada berkembang cukup lambat, arah dan orientasi Filsafat IImu di Canada memfokuskan pada dua aspek yaitu pertama, pemisahan atas ilmu dan teknologi. Kedua, pengembangan pemikiran tentang kosmologi, epistemologi dan disiplin Filsafat. Filsafat IImu menjadi disiplin otonom di kanada dikenal pada periode tahun 1951-1961.

Beberapa perguruan tinggi di Indonesia sampai sekarang masih mengajarkan Filsafat IImu sebagai disiplin untuk memperkuat dan melengkapi para akademisi dan mahasiswa dalam memahami seluk beluk ilmu. Pada umumnya, Filsafat IImu diajarkan pada jenjang S1 dan S2, serta S3. Tergantung dari kebutuhan dan kepentingan dari disiplin untuk untuk memberikan materi Filsafat IImu sebagai disiplin tersendiri. Sebagaimana Malian (2010) mengungkapkan bahwa Filsafat IImu merupakan cabang IImu Filsafat yang sangat berguna untuk menjelaskan apa tujuan ilmu bagi manusia. Secara garis besar, Filsafat IImu mengemukakan alasan yang mendasar mengapa pengetahuan diperlukan bagi keteraturan dalam hidup manusia. Begitu juga Widyawati (2013) menjelaskan bahwa Filsafat IImu memperjelas eksistensi ilmu yang membutuhkan pengetahuan lain sebagai sarana berpikir dan sarana komunikasi keilmuannya. Sarana ini antara lain adalah bahasa, logika, matematika, statistika, dan teknik analisis data lainnya.

Kajian ini merujuk pada penelitian sebelumnya yang telah dilakukan para pemikir dan pemerhati Filsafat IImu. Adapun penelitian sebelumnya yang pernah ada adalah seperti penelitian Niiniluoto (1993), yang menguraikan tentang Filsafat IImu di Finlandia pada periode 1970-1990. Tulisan tersebut menguraikan tentang posisi dan sejarah pemikiran Filsafat Ilmu masuk di negara Finlandia dan latar belakang yang mempengaruhinya. Lalu, penelitian Ujlaki (1994) yang membahas tentang Filsafat Ilmu di Hungaria. Tulisan tersebut menguraikan tentang cikal bakal munculnya Filsafat IImu dan perkembangan Filsafat IImu di Hungaria dalam konteks sejarah dan politik yang mempengaruhi perkembangan ilmu di Hungaria pada periode tahun 1970-an. Selanjutnya, penelitian Nordenstam dan Skjervheim (1973), yang membahas Filsafat Ilmu di Norwegia. Tulisan tersebut menguraikan tentang perkembangan pemikiran Filsafat IImu di Norwegia setelah merdeka tahun 1814, yang menjadikan negara Norwegia sebagai negara yang memberikan ruang kebebasan dan universitas untuk pertama kalinya didirikan pada tahun tersebut. Dalam perkembangannya, pemikiran tentang ilmu pengetahuan mulai lahir dan pada tahun 1936 ketika salah satu pemikir Arne Naess menerbitkan buku dari doktornya berjudul "Erkenntnis und wissenschaftliches Ver halten" (Pengetahuan dan Perilaku IImiah). Dari sejak itu perdebatan tentang Filsafat IImu di Norwegia mulai terjadi khususnya membahas persoalan tentang Filsafat IImu Sosial; Witt-Hansen (1970) menguraikan tentang Filsafat IImu di Denmark, dalam tulisan ini menjelaskan perdebatan tentang Filsafat Ilmu yang berkembang di Denmark mengacu pada dua karya pemikiran yaitu Niels Bohr (1885-1962) and Jorgen Jorgensen (18941969). Fokus yang diperdebatkan terkait Filsafat IImu antara lain persoalan tentang dunia luar (external world), persoalan tentang induksi, persoalan dialektika Marxis, dan perdebatan tentang Filsafat tradisi dan modern.

Berdasarkan dari kajian dan penelitian di atas, upaya untuk mendeskripsikan dan menganalisis orientasi Filsafat IImu di Indonesia menjadi penting dilakukan. Oleh karena itu, tujuan dari kajian ini adalah untuk mendeskripsikan dan menganalisis tentang orientasi dan perkembangan Filsafat IImu di Indonesia dari aspek paradigma ilmu dan sejarah pemikiran dari Filsafat IImu di Indonesia. Tulisan ini menjadi krusial untuk dilakukan karena selama ini persoalan studi dan pembahasan Filsafat Ilmu belum mengarah pada upaya untuk mempelajari titik pijak Filsafat IImu di Indonesia, mulai dari mana dan bersumber dari dasar ontologis, epistemologis, dan aksiologis seperti apa. Dalam pembahasan Filsafat IImu pada kelas Filsafat IImu (secara khusus mata kuliah Filsafat IImu) tema pembahasan masih berpijak pada sejarah ilmu di negaranegara barat, serta pemikiran tentang ilmu yang berkembang di negara negara barat, tetapi belum menunjukkan kontekstualisasi Filsafat IImu di negara mana studi tentang Filsafat IImu dan kehidupan masyarakat di Indonesia dilakukan. Tulisan ini berupaya untuk membangun dasar 
berpikir dan berpijak tentang sebenarnya arah dan orientasi Filsafat Ilmu di Indonesia, mulai dari aspek ontologis, epistemologis, dan aksiologis. Dengan adanya tulisan ini, diharapkan pembelajaran dan wacana tentang Filsafat IImu di Indonesia dapat mengarah dan berorientasi pada non western oriented.

\section{Metode}

Metode penelitian ini menggunakan pendekatan kualitatif dengan menganalisis sumber atau data dari buku teks, jurnal ilmiah, dokumen, silabus, dan bahan ajar dalam perkuliahan Filsafat IImu. Bahan penelitian tersebut dijadikan sebagai dasar untuk menganalisis tentang arah dan orientasi Filsafat IImu di Indonesia sebagai kajian dan studi humaniora karena sampai sejauh ini perkembangan pemikiran Filsafat IImu di Indonesia dapat dilacak dari dokumen, buku teks, jurnal ilmiah yang diterbitkan. Metode analisis yang digunakan ialah interpretasi, heuristik, dan analisis wacana kritis.

\section{Hasil dan Pembahasan \\ a. Konstruksi IImu}

IImu mulai muncul dari hakikat manusia yang memiliki gagasan dan keinginan untuk mendapatkan sesuatu yang baru. Manusia hidup di dunia ini pada hakikatnya mempunyai keinginan untuk mencari pengetahuan dan kebenaran. Pengetahuan merupakan hasil proses dari usaha manusia untuk tahu (Atabik, 2014). Ilmu dikonstruksikan secara sistematis dan tematis oleh manusia. IImu dapat memengaruhi kehidupan manusia dan dapat mengubah peradaban manusia. Sutopo dan Tritularsih (2017) merekonstruksi posisi dan kedudukan pemikiran ilmu dalam dunia industri dalam beberapa periode. Pada periode pertama, perubahan dari pengerjaan sistem manual dengan tenaga manusia menjadi sistem pabrikan dengan beberapa temuan di bidang teknologi terjadi pada periode revolusi industri di Inggris. Peningkatan produktivitas melalui analisis dan perancangan metode kerja dengan prinsip-prinsip ilmiah. Pada periode berikutnya, awal abad ke-20, penggunaan pendekatan matematik dan optimasi klasik sebagai metoda untuk peningkatan produktivitas. Pada pertengahan abad ke-20, sudah mulai menggunakan pendekatan Cybernetic, Soft System Thinking, Critical System Thinking, dan Total Intervention System. Pada akhir abad ke-20, jejaring kerjasama dan teknologi informasi sudah mulai digunakan.

Era abad ke-20 ini memiliki tantangan tersendiri. Era abad tersebut adalah era global di mana teknologi informasi berkembang pesat, sehingga berbagai informasi dan pengetahuan dapat berkembang dan muncul silih berganti tanpa ada kontrol yang ketat. Salah satu tantangan yang mendasar ialah di mana posisi dan kedudukan ilmu dalam peradaban manusia dijadikan untuk membangun fondasi kehidupan. Pada awal perkembangan, ilmu muncul untuk membantu manusia membangun fondasi ilmiah dan mencari kebenaran ilmiah. Ilmuwan melakukan eksperimen, penelitian, dan berbagai macam percobaan untuk mendapatkan metode yang sahih dan kebenaran ilmu pengetahuan. Sehingga, konstruksi ilmu pada dasarnya adalah untuk membangun kebenaran dan pengetahuan yang solid. Menurut Sutopo dan Tritularsih (2017), tantangan lain dari dampak era informasi global adalah peran manusia sudah tergeserkan oleh teknologi. Itu merupakan permasalahan juga dari revolusi industri yang secara fundamental akan mengubah cara kerja, bekerja, dan berhubungan satu dengan yang lain. Ini adalah bentuk transformasi yang sedang terjadi. Namun, sejauh transformasi ini berdampak positif, konsekuensi yang timbul harus bisa diseimbangkan dengan munculnya peluang yang ada. Di sisi lain, tanpa mengesampingkan peran manusia yang telah tergantikan oleh mesin, manusia mempunyai peran yang sangat penting sebagai penggerak teknologi. Kajian ilmu secara teoritis dan paradigmatik banyak dibahas dalam disiplin ilmu Filsafat. Filsafat telah berkembang menjadi ilmu-ilmu khusus, di dalam Filsafat sendiri mempunyai cabangcabang yang terus berkembang sesuai dengan perkembangan permasalahan yang dihadapi. Cabang filsafat yang pokok adalah: Ontologi, Epistemologi-Metodologi, Logika, Etika, dan Estetika (Widyawati, 2013). Salah satu cabang Filsafat khusus yang membahas tentang perdebatan seluk-beluk ilmu ialah Filsafat IImu. Filsafat IImu memegang peranan penting sebagai peletak dasar-dasar pondasi keilmuan. IImu adalah representasi makna sesungguhnya dari realitas, bentuk, mode, kuantitas, substansi, dan esensi sesuatu oleh jiwa yang rasional lagi tenang (Maerani, 2015). Namun demikian, perjalanan pemikiran Filsafat IImu dari sebuah keilmuan tidak dapat dipisahkan dari perkembangan jaman atau sosiokultural. Paradigma keilmuan mengalami perkembangan bahkan perdebatan pada tiap zamannya (Malian, 2010). Filsafat IImu dapat dimaknai sebagai Filsafat yang berkaitan dengan atau tentang ilmu. Pemahaman lain menjelaskan bahwa Filsafat IImu merupakan bagian dari 
Filsafat pengetahuan secara umum, ini dikarenakan ilmu itu sendiri merupakan suatu bentuk pengetahuan dengan karakteristik khusus (Widyawati, 2013).

Konstruksi ilmu dalam pemikiran Filsafat berkembang menjadi suatu kajian penting karena ilmu yang dimaksud dalam kajian ini adalah ilmu yang membawa pada arah perubahan, penemuan, penggunaan metode yang sahih dalam mendekati masalah, dan melahirkan pengetahuan yang sistematis. Akhirnya ilmu dapat membentuk pengetahuan baru. Filsafat IImu awalnya digunakan dalam ilmu alam, tetapi saat ini telah dipinjam untuk menjelaskan disipiln ilmu lain, akuntansi misalnya. Akuntansi sendiri telah menggunakan metode scientific di dalam proyek riset. Juga ada usaha menggunakan Filsafat IImu untuk menggambarkan akuntansi. Paradigma Khun telah digunakan oleh Wells (1976) dan STTA (1977) untuk menjelaskan perkembangan akuntansi saat ini. Belkaooui $(1981 ; 1985)$ menggunakannya untuk menggambarkan akuntansi sebagai multiparadigm science. STTA (1977) juga mengakui selain pandangan Kuhn, perspektif lain seperti Lakatos juga digunakan. Banyak peneliti akuntansi yang menganggap bahwa induktivist interpretation merupakan Filsafat Ilmu yang relevan untuk akuntansi. Hal ini disebabkan peneliti akuntansi untuk merumuskan hipotesis dan berusaha membuktikan kebenaran hipotesis tersebut (Hardiwinoto, 2009). Hasil dari pemikiran Filsafat ini telah melahirkan pengetahuan baru di bidang akuntansi sebagai pengembangan dari ilmu matematika dan ilmu hitung dan ukur. Konstruksi ilmu yang dibentuk tidak hanya sekedar untuk membangun pengetahuan dan mencapai kebenaran tetapi juga melahirkan pengetahuan baru dan mengembangkan ilmu pengetahuan. Oleh karena itu, baik Filsafat maupun ilmu pengetahuan, intinya ialah berpikir. Perbedaan yang mendasar ialah jika Filsafat memikirkan atau menjangkau sesuatu itu secara menyeluruh, maka ilmu memikirkan atau menjangkau bagian-bagian tertentu tentang sesuatu. Jika Filsafat menjangkau sesuatu itu secara spekulatif atau perenungan dengan menggunakan metode berpikir deduktif, maka ilmu menggunakan pendekatan empiris atau ilmiah dengan menggunakan metode berpikir induktif di samping metode berpikir deduktif (Soelaiman, 2019). Soelaiman (2019) menekankan bahwa ilmu adalah pengetahuan, tetapi pengetahuan belum tentu merupakan ilmu, sebab pengetahuan dapat diperoleh dengan atau tanpa metode ilmiah. Artinya, dapat diperoleh melalui pengalaman sehari-hari atau berupa informasi yang kita terima dari seseorang yang memiliki kewibawaan atau otoritas tertentu. Sedangkan, ilmu hendaknya diperoleh dengan metode ilmiah, yaitu dengan menggunakan metode berpikir deduktif dan induktif.

\section{b. Posisi Filsafat IImu di Indonesia}

Dalam berbagai studi dan kajian, Filsafat Ilmu dalam konteks Indonesia dibahas sebagai salah satu kajian yang dapat memberikan kontribusi pemikiran, pengembangan keilmuan dari disiplin ilmu khusus yang lain seperti IImu Pendidikan, Hukum, dan Ekonomi. Nasrullah (2007) menjelaskan bahwa Filsafat IImu memiliki peran penting dalam memajukan IImu Ekonomi karena dari Filsafat IImu telah melahirkan pemikiran ekonomi baik teoritis maupun terapan. Berbagai temuan ilmiah di bidang manajemen, produksi, pemasaran, sumber daya manusia dan keuangan telah mampu membawa dampak terhadap modernisasi sistem industri dan perdagangan dunia. Filsafat IImu Pengetahuan merupakan filsafat khusus yang membahas berbagai macam hal yang terkait dengan ilmu pengetahuan. Sebagai Filsafat, Filsafat IImu Pengetahuan membahas ilmu pengetahuan sebagai objeknya secara rasional (kritis, logis, dan sistematis), menyeluruh, dan mendasar. Filsafat IImu Pengetahuan berusaha memperoleh pemahaman tentang ilmu pengetahuan secara benar, jelas, lengkap, serta mendalam untuk mendapatkan kerangka pokok serta unsur-unsur hakiki yang kiranya menjadi ciri khas dari ilmu pengetahuan yang sebenarnya (Wahana, 2016). Dalam kajian Filsafat Ilmu, pengetahuan dan ilmu dibedakan menjadi dua posisi yaitu pengetahuan adalah keseluruhan gagasan, pemikiran, ide, konsep dan pemahaman yang dimiliki manusia tentang dunia dan segala isinya, termasuk manusia dan kehidupannya. Sedangkan, pengetahuan adalah keseluruhan sistem pengetahuan manusia yang telah dibakukan secara sistematis (Soelaiman, 2019).

Posisi Filsafat IImu di Indonesia berdasarkan dari kajian dan analisis penelitian ini menunjukkan bahwa awal mula perdebatan tentang Filsafat IImu di Indonesia berpijak pada tiga pemikiran utama yaitu: pemikiran The Liang Gie yang membahas dimensi ilmu dan struktur ilmu dalam bukunya berjudul Pengantar Filsafat IImu. Pemikiran The Liang Gie yang memperjelas antara definisi ilmu dan dimensi ilmu. The Liang Gie menjelaskan tentang dimensi ilmu terdiri atas cabang ilmu, pengetahuan reflektif abstrak, dan aspek realitas. Cabang ilmu diartikan sebagai cabang dari ilmu tertentu seperti ekonomi, linguistik, matematika, politik, psikologis, dan sosiologis. Sedangkan pengetahuan reflektif-abstrak terdiri atas pengetahuan filsafati dan logis. 
Dimensi ilmu dari aspek realitas mengarahkan pada dimensi kebudayaan, sejarah, kemanusiaan, rekreasi, sistem, dan dimensi lainnya (Gie 2012). Posisi berikutnya, pemikiran dari Jujun S. Suriasumantri yang menekankan tentang hakikat ilmu bahwa ilmu tidak menuntut adanya hubungan sebab akibat yang mutlak (Suriasumantri, 2015). Posisi ilmu dalam konteks yang disampaikan Suriasumantri menekankan pada esensi pengetahuan, sumber pengetahuan, dan dasar moralitas ilmu. Esensi ilmu adalah menemukan pengetahuan yang hakiki. Sumber kebenaran IImu ditentukan dari cara berpikir yang dilakukan menurut persyaratan keilmuan, dan dimensi nilai dari ilmu ialah moralitas ilmu bertujuan untuk kebaikan umat manusia. Pada dasarnya kajian ini menunjukkan bahwa posisi Filsafat Ilmu dalam membangun kontruksi ilmu di Indonesia menekankan pada pemikiran Filsafat IImu barat yang membahas tentang hakikat ilmu dari aspek ontologis, epistemologis, dan aksiologis. Oleh karena itu, orientasi Filsafat Ilmu yang berkembang di Indonesia mengacu pada paradigma barat yang membahas ilmu dari perspektif Filsafat barat. Wacana yang ditawarkan dari kajian Filsafat IImu pada umumnya memiliki unsur yang lebih dominan pada wacana Filsafat ilmu pengetahuan barat.

Persoalan Filsafat IImu yang didiskusikan dalam kajian dan kegiatan akademik di Indonesia lebih menekankan pada persoalan-persoalan kehidupan di Indonesia dipandang dari kajian Filsafat IImu. Dinamika dan perdebatan tentang posisi dan konstruksi ilmu dalam Filsafat IImu belum nampak digali dan dikaji oleh para ahli dan pemikir Filsafat IImu. Pola pemahaman dan pemikiran yang berkembang dalam kajian Filsafat IImu dan wacana akademik tentang Filsafat IImu lebih menekankan pada Filsafat IImu sebagai fondasi dari pembentukan pengetahuan para intelektual di Indonesia berdasarkan pada disiplin yang dipelajari. Berdasarkan dari berbagai literatur yang berkembang tentang Filsafat IImu di Indonesia, dapat terlihat bahwa arah dan orientasi pengembangan Filsafat IImu di Indonesia secara teoritis berpijak pada pola berpikir filsafat ilmu barat. Berikut ini berbagai referensi tentang Filsafat ilmu yang berkembang di Indonesia.

Tabel 1. Berbagai referensi yang terbit tentang Filsafat IImu di Indonesia

\begin{tabular}{|c|c|c|c|}
\hline No & Penulis & Judul & $\begin{array}{l}\text { Tahun, } \\
\text { Penerbit }\end{array}$ \\
\hline 1. & $\begin{array}{ll}\text { Wilhendri } & \text { Azwar } \\
\text { Muliono } & \end{array}$ & $\begin{array}{l}\text { Filsafat IImu Cara Mudah Memahami Filsafat } \\
\text { IImu }\end{array}$ & $\begin{array}{l}2019, \\
\text { Prenadamedia }\end{array}$ \\
\hline 2. & Beni Ahmad Saebani & $\begin{array}{l}\text { Filsafat IImu Kontemplasi Filosofis tentang } \\
\text { Seluk Beluk Sumber dan Tujuan IImu } \\
\text { Pengetahuan }\end{array}$ & $\begin{array}{l}\text { 2009, Pustaka } \\
\text { Setia Bandung }\end{array}$ \\
\hline 3. & Jerome R. Ravert & $\begin{array}{l}\text { Filsafat IImu Sejarah \& Ruang Lingkup } \\
\text { Bahasan }\end{array}$ & $\begin{array}{ll}2014, & \text { cetakan } \\
\text { ke-4, } & \text { Pustaka } \\
\text { Pelajar } & \end{array}$ \\
\hline 4. & Mukhtar Latif & Orientasi ke Arah Pemahaman Filsafat IImu & $\begin{array}{l}\text { 2014, cetakan } 1, \\
\text { Prenadamedia }\end{array}$ \\
\hline 5. & Akhyar Yusuf Lubis & Filsafat IImu Klasik Hingga Kontemporer & $\begin{array}{l}\text { 2016, Rajawali } \\
\text { Pers }\end{array}$ \\
\hline 6. & $\begin{array}{l}\text { Jujun } \\
\text { Suriasumantri }\end{array}$ & $\begin{array}{l}\text { IImu dalam Perspektif sebuah Kumpulan } \\
\text { Karangan tentang Hakikat IImu }\end{array}$ & $\begin{array}{l}\text { 2015, Yayasan } \\
\text { Putaka Obor } \\
\text { Indonesia }\end{array}$ \\
\hline 7. & $\begin{array}{ll}\text { Jujun } & \text { S. } \\
\text { Suriasumantri } & \end{array}$ & Filsafat IImu sebuah Pengantar Populer & $\begin{array}{l}\text { 2010, Pustaka } \\
\text { Sinar Harapan }\end{array}$ \\
\hline 8. & $\begin{array}{l}\text { Sabarti Akhadiah dan } \\
\text { Winda Dewi Listyasari }\end{array}$ & Filsafat IImu Lanjutan & $\begin{array}{l}2011, \\
\text { Prenadameida }\end{array}$ \\
\hline 9. & The Liang Gie & Pengantar Filsafat IImu & $\begin{array}{l}2012, \quad \text { Liberty } \\
\text { Yogyakarta }\end{array}$ \\
\hline 10. & $\begin{array}{l}\text { Muhammada Syukri, } \\
\text { Albani Nasution, dan } \\
\text { Rizki Muhammad } \\
\text { Haris }\end{array}$ & Filsafat IImu & $\begin{array}{l}\text { 2018, } \\
\text { Rajagrafindo }\end{array}$ \\
\hline 11. & Surajiyo & $\begin{array}{l}\begin{array}{l}\text { Filsafat IImu \& } \\
\text { Indonesia }\end{array} \\
\end{array}$ & $\begin{array}{lr}2017, & \text { cetakan } \\
\text { ke-10, } & \text { Bumi } \\
\text { Aksara } & \end{array}$ \\
\hline
\end{tabular}


Jurnal Filsafat Indonesia, Vol 4 No 3 Tahun 2021

ISSN: E-ISSN 2620-7982, P-ISSN: 2620-7990

\begin{tabular}{|c|c|c|c|}
\hline 12. & Nunu Burhanuddin & Filsafat IImu & $\begin{array}{l}2018, \\
\text { Prenadamedia }\end{array}$ \\
\hline 13. & A.Susanto & $\begin{array}{l}\text { Filsafat IImu Suatu Kajian dalam Dimensi } \\
\text { Ontologis, Epistemologis, dan Aksiologis }\end{array}$ & $\begin{array}{lr}2016, & \text { cetakan } \\
\text { ke-7, } & \text { Bumi } \\
\text { Aksara } & \end{array}$ \\
\hline 14. & $\begin{array}{l}\text { Tim Dosen Filsafat } \\
\text { IImu }\end{array}$ & $\begin{array}{l}\text { Filsafat IImu sebagai dasar Pengembangan } \\
\text { IImu Pengetahuan }\end{array}$ & 2016, Liberty \\
\hline 15. & Mohammad Adib & $\begin{array}{l}\text { Filsafat IImu, Ontologi, Epistemologi, } \\
\text { Aksiologi, dan Logika Ilmu Pengetahuan }\end{array}$ & $\begin{array}{l}\text { 2011, Pustaka } \\
\text { Pelajar }\end{array}$ \\
\hline 16. & Erliana Hasan & $\begin{array}{l}\text { Filsafat IImu dan Metodologi Penelitian ilmu } \\
\text { Pemerintahan }\end{array}$ & $\begin{array}{l}\text { 2014,Ghalia } \\
\text { Indonesia }\end{array}$ \\
\hline 17. & $\begin{array}{l}\text { Rizal Mustansyir dan } \\
\text { Misnal Munir }\end{array}$ & Filsafat IImu & $\begin{array}{ll}2013, & \text { cetakan } \\
\text { ke-13, } & \text { Pustaka } \\
\text { Pelajar } & \end{array}$ \\
\hline 18. & Setya Widyawati & Filsafat IImu & 2018, ISI Press \\
\hline 19. & Mohammad Muslih & $\begin{array}{l}\text { Filsafat Ilmu Kajian Atas Asumsi Dasar, } \\
\text { Paradigma, dan Kerangka Teori IImu } \\
\text { Pengetahuan }\end{array}$ & 2016, Lesfi \\
\hline 20. & Paulus Wahana & Filsafat IImu Pengetahuan & $\begin{array}{l}\text { 2016, Pustaka } \\
\text { Diamond }\end{array}$ \\
\hline 21. & $\begin{array}{l}\text { Saifullah Idris dan } \\
\text { Fuad Ramly }\end{array}$ & $\begin{array}{l}\text { Dimensi Filsafat IImu dalam Diskursus } \\
\text { Integrasi IImu }\end{array}$ & $\begin{array}{l}2016, \\
\text { Darussalam } \\
\text { Publishing }\end{array}$ \\
\hline
\end{tabular}

Sumber: Koleksi Peneliti/Penulis, 2021.

Berdasarkan tabel di atas, ditunjukkan bahwa titik tolak Filsafat IImu sebagai bahan ajar dan pengajaran dalam pendidikan dan pembelajaran Filsafat IImu mengacu pada dua paradigma, yaitu paradigma pengenalan tentang Filsafat secara umum dan paradigma pemahaman tentang hakikat ilmu dan pengetahuan. Orientasi Filsafat IImu di Indonesia dalam buku teks pembelajaran Filsafat IImu secara umum membahas tiga hal yaitu: sejarah Filsafat, sejarah pemikiran tokoh pemikir tentang Filsafat IImu, dan hakikat ilmu (Muliono, 2019). Referensi di atas menunjukkan bahwa Filsafat IImu dimaknai sebagai teori tentang Filsafat IImu sehingga materi, bahan bahan, dan uraian tentang Filsafat ilmu secara sistematis dikembangkan berdasarkan pada sejarah dan pemikiran Filsafat barat. Sehingga, persoalan-persoalan yang muncul dalam Filsafat IImu ialah persoalan yang bersifat klasik, modern, dan kontekstual. Persoalan klasik berpijak tentang problem pengetahuan dan metode mendapatkan ilmu, problem modern tentang persoalan kehidupan manusia (yang berkaitan dengan perkembangan ilmu pengetahuan), dan problem kontekstual ialah persoalan ilmu yang dihadapi pada setiap disiplin ilmu. Arah dan orientasi Filsafat IImu yang berkembang di Indonesia belum digali dan ditelusuri dari dinamika dan perkembangan disiplin ilmu yang ada di Indonesia. Persoalan persoalan dari disiplin ilmu yang dihadapi baik secara teoritis dan praktis belum diangkat sebagai basis arah dan orientasi filsafat ilmu di Indonesia. Sehingga, tawaran paradigma yang dimuncul belum terlalu nampak terjadi.

\section{Simpulan dan Saran}

Pembahasan arah dan orientasi Filsafat IImu di Indonesia dalam kajian dan penelitian ini menyimpulkan bahwa kedudukan dan posisi Filsafat IImu sebagai paradigma yang dikembangkan di Indonesia dalam kegiatan akademik, khususnya pengembangan ilmu di Indonesia, meletakkan Filsafat IImu sebagai obyek formal artinya Filsafat IImu menjadi dasar untuk melihat dan menganalisis tentang hakikat ilmu yang berkembang pada suatu disiplin ilmu tertentu atau pemikiran tertentu di Indonesia. Filsafat Ilmu dikembangkan dan diajarkan mengacu pada paradigma Filsafat IImu yang berkembang di barat. Struktur yang dibangun dalam mengembangkan Filsafat IImu muncul dari kajian sejarah Filsafat IImu mulai dari pengetahuan dasar tentang Filsafat sampai pada hakikat ilmu. Arah dan orientasi Flsafat IImu sebagai disiplin ilmu Filsafat yang dikembangkan di Indonesia muncul dari pengaruh berbagai literatur yang berkembang masih didominasi pada orientasi Filsafat barat. Untuk itu, pengembangan Filsafat IImu di Indonesia perlu dirumuskan ulang untuk dapat menemukan ciri khas dan karakter tentang pemikiran Filsafat Ilmu di Indonesia yang otentik. 


\section{Ucapan Terima Kasih}

Penulis mengucapkan terima kasih atas kesempatan yang diberikan oleh Magister Psikologi Universitas Mercu Buana Yogyakarta yang telah memberikan ruang bagi penulis untuk mengajar di Program Studi Magister Psikologi.

\section{Daftar Pustaka}

Achadah, A., dan Fadil M. (2020). Filsafat IImu: Pertautan Aktivitas IImiah, Metode IImiah dan Pengetahuan Sistematis, Jurnal Pendidikan Islam Vol. 4, No. 1, Juni 2020, hal. 130-14.

Atabik, A. (2014). "Teori Kebenaran Perspektif Filsafat IImu: Sebuah Kerangka untuk Memahami Konstruksi Pengetahuan Agama", Fikrah, Vol. 2, No. 1, Juni 2014, STAIN, Kudus.

Butts, R. (1974). Philosophy of Science in Canada. Source: Zeitschrift für allgemeine Wissenschaftstheorie / Journal for General Philosophy of Science, Vol. 5, No. 2 (1974), pp. 341-358. Published by: Springer. Stable URL: https://www.jstor.org/stable/25170328.Accessed: 27-09-2018 12:50.

Gie, T.L. (2012). Pengantar Filsafat IImu, cetakan keduabelas, Yogyakarta: Liberty.

Hamdan, A. (2018). "Kebenaran IImiah Dalam Perspektif Filsafat IImu (Suatu Pendekatan Historis dalam Memahami Kebenaran IImiah dan Aktualisasinya dalam Bidang Praksis)", Majalah IImu Pengetahuan dan Pemikiran Keagamaan Tajdid, Vol. 21, No. 1, Juli 2018, Fakultas Ushuluddin Universitas Islam Negeri Imam Bonjol Padang. Padang.

Hardiwinoto. (2009). Filsafat IImu dan Perkembangan IImu Akuntansi", Jurnal Ilmiah Value Added Vol 5, No.2 (2009), Program Studi Manajemen Fakultas Ekonomi Universitas Muhammadiyah, Semarang.

Kirom, S. (2011). Filsafat IImu dan Arah Pengembangan Pancasila: Relevansinya dalam Mengatasi Persoalan Kebangsaan, Jurnal Filsafat Volume 21 Nomor.2, Agustus. Hal.99117.

Maerani, I.A. (2015). "Filsafat IImu dalam Perspektif Hukum Islam" Jurnal Hukum Volume XXXI, No. 1, Juni 2015, Fakultas Hukum Universitas Islam Sultan Agung, semarang.

Malian, S. (2010). "Perkembangan Filsafat IImu serta Kaitannya dengan Teori Hukum", UNISIA, Vol. XXXIII No. 73 Juli 2010, Universitas Islam Indonesia, Yogyakarta.

Meliono, V.I. (2004). "Paradigma Baru dalam Pendidikan IImu Kedokteran: Filsafat IImu Kedokteran", EBERS PAPYRUS, Vol.10, No.1, Maret 2004, Fakultas Kedokteran Universitas Tarumanegara, Jakarta.

Muliono. (2019). Filsafat Ilmu Cara Mudah Memahami Filsafat Ilmu. Jakarta: Prenada Media.

Nasrullah, Y. (2007). "Peran Filsafat IImu terhadap IImu Ekonomi dan Pengembangan Para Sarjananya", UNISIA, Vol. XXX No. 65 September 2007, Universitas Islam Indonesia, Yogyakarta.

Niiniluoto, I. (1993). "Philosophy of Science in Finland: 1970-1990", Source: Journal for General Philosophy of Science / Zeitschrift für allgemeine Wissenschaftstheorie, Vol. 24, No. 1 (1993), pp. 147-167 Published by: Springer Stable URL: https://www.jstor.org/stable/25170956 Accessed: 27-09-2018 12:34.

Nordenstam, T. dan Skjervheim, H. (1973). "Philosophy of Science in Norway", Source: Zeitschrift für allgemeine Wissenschaftstheorie / Journal for General Philosophy of Science, Vol. 4, No. 1 (1973), pp. 147-164 Published by: Springer Stable URL: https://www.jstor.org/stable/25170273 Accessed: 27-09-2018 12:31.

Soelaiman, D.A. (2019). Filsafat IImu Pengetahuan Perspektif Barat Dan Islam, Bandar Publishing, Banda Aceh.

Suriasumantri, J .S.(2015). IImu dalam Perspektif, Jakarta: Yayasan Obor.

Sutopo, Wahyudi, Tritularsih, Yustina. (2017). "Peran Keilmuan Teknik Industri Dalam Perkembangan Rantai Pasokan Menuju Era Industri 4.0", Prosiding Seminar dan Konferensi Nasional IDEC 2017 ISSN: 2579-6429 Surakarta, 8-9 Mei 2017.

Tutik, T.T. (2014). "IImu Hukum: Hakekat Keilmuannya Ditinjau Dari Sudut Filsafat IImu Dan Teori IImu Hukum", Jurnal Hukum dan Pembangunan Tahun ke-44 No.2 April-Juni 2014, Universitas Indonesia, Jakarta.

Ujlaki, G. (1994). "Philosophy of Science in Hungary", Source: Journal for General Philosophy of Science / Zeitschrift für allgemeine Wissenschaftstheorie, Vol. 25, No. 1 (1994), pp. 157175 Published by: Springer Stable URL: https://www.jstor.org/stable/25170986 Accessed: 27-09-2018 12:22.

Wahana, P. (2016). "Persepsi Mahasiswa Terhadap Perkuliahan Filsafat IImu Pengetahuan Dengan Pembelajaran Kontekstual-Reflektif Berbasis Pedagogi Ignasian”, Jurnal 
Penelitian (Edisi Khusus PGSD). Volume 20, No. 2, Desember 2016, hlm. 132-143, Universitas Sanata Dharma, Yogyakarta.

Whitrow, G.J. (1956). The Study of the Philosophy of Science, The British of Journal the Philosophy of Science, Vol VII, November, 1956, No.27, This content downloaded from 202.43.93.8 on Thu, 27 Sep 2018 12:41:28 UTC All use subject to https://about.jstor.org/terms.

Widyawati, S. (2013). "Filsafat IImu Sebagai Landasan Pengembangan IImu Pendidikan", GELAR, Jurnal Seni Budaya, Volume 11 No. 1 Juli 2013, Institut Seni Indonesia (ISI), Surakarta, Surakarta.

Wilujeng, S.R. (2013). "Filsafat, Etika Dan Ilmu: Upaya Memahami Hakikat Ilmu Dalam Konteks Keindonesiaan" , Humanika, Vol 17, No 1: Juni 2013, Fakultas IImu Budaya, UNDIP, Semarang.

Witt-Hansen, J. (1970). "Philosophy of Science (Wissenschaftstheorie) in Denmark", Source: Zeitschrift für allgemeine Wissenschaftstheorie / Journal for General Philosophy of Science, Vol. 1, No. 2 (1970), pp. 264-283 Published by: Springer Stable URL: https://www.jstor.org/stable/25170186 Accessed: 27-09-2018 12:44. 